\title{
A Study on Technological Pedagogical and Content Knowledge among Teacher-Educators in Punjab Region
}

\author{
Dr. Nimisha Beri, Lalit Sharma
}

\begin{abstract}
Effective ICT integration requires teachers to gain proficiency in TPACK (knowledge of technology, content, pedagogy, and the intersection of these) (Mishra \& Koehler, 2006; Archambault, \& Crippen, 2009). TPACK is perceived as a dynamic framework representing the knowledge that teachers must confide on to design and implement curriculum and instruction while guiding their students' thinking and learning with digital technologies in various subjects. TPACK competencies are very fruitful in making teaching learning process an ecstatic experience as it would make notable changes in the interaction pattern of educators. Even though TPACK is a boon in teaching and learning, it is a fact that the fruits of these skills are not appropriately utilized by the stakeholders. This study was aimed to evaluate the Technological Pedagogical and Content Knowledge (TPACK) competencies among teacher-educators in teaching training colleges in the state of Punjab, (India). A five-point Likert scale constructed and validated by the researchers was used in the present study. Instrumental survey method was practiced as a tool for the present research. 200 teacher-educators working in different teaching-training colleges in the state of Punjab, (India) were selected through random sampling method. The collected data was analyzed by using SPSS 22.0 software. The findings of the study show that the technological pedagogical and content knowledge (TPACK) competencies have found high in the teacher-educators of Punjab region. The study revealed that there are statistically significant differences in the (TPACK) competencies of teacher-educators with respect to gender, locality of college, stream and type of colleges.
\end{abstract}

Keywords: teacher-educators, technological pedagogical and content knowledge (TPACK), teacher-training colleges.

\section{INTRODUCTION}

Science and Technological developments have brought many challenges and opportunities and influence the world like no other invention in the recent past. Yilmaz, M. (2007). The field of education has also been greatly influenced by science and technology, which have certainly affected whole education process. (Yusuf, 2005). In order to ensure that education should not deviate from its normal path teachers have to become techno-pedagogues (Saleem, 2017). Transformation of teachers to techno-pedagogues would increase the capabilities of teachers and make the teaching-learning process effective and efficient and they will bring the entire world into the class-room as well as to make students competitive in the international arena.

The Education Commission (1964-66) of India recognized this impact of teachers in powerful words, "No system can rise above the status of its teacher". Experiences of various countries reveal that the most effective way to develop good teachers in a dynamic and changing environment is to begin with a well developed in-service teacher education programme. Therefor society should make some provision for continuous professional development of in-service teachers so that they can contribute in the growth of society. (Goldhabar and Brewer, 2000).

Better teaching was not done merely introducing technology or ICT as a compulsory subject in schools and teacher education curriculum. The meaningful use of ICT in the classroom demands the teachers to mix TPACK competencies for the specific subject matter to be taught, (Koehler and Mishra, 2005).

Today the TPACK competencies are very much needed for teacher-educators because they facilitate the prospective teachers and make them to become techno-pedagogues Hence teacher-educators should be provided opportunities to get practical and pedagogical skills by using the recent technologies during their teaching-learning process. (Yurdakul 2011). According to Lee and Tsai (2010) "Techno-pedagogical competency is the art of integrating sound pedagogic principles of teaching/learning with the use of technology. It refers to weaving the techniques of the craft of teaching into the learning environment itself".

"In TPACK, there are three areas of knowledge, namely: content, pedagogy, and technology. Content is the subject matter that is to be taught. Technology encompasses modern technologies such as computer, Internet, digital video and commonplace technologies including overhead projectors, blackboards, and books. Pedagogy describes the collected practices, processes, strategies, procedures, and methods of teaching and learning. It also includes knowledge about the aims of instruction, assessment, and student learning." (Archambault \& Crippen, 2009; Cox \& Graham, 2009).

TPACK is a teacher knowledge framework developed by including technology knowledge into the teacher knowledge framework that Shulman (1986) basically determined as "pedagogical content knowledge". 


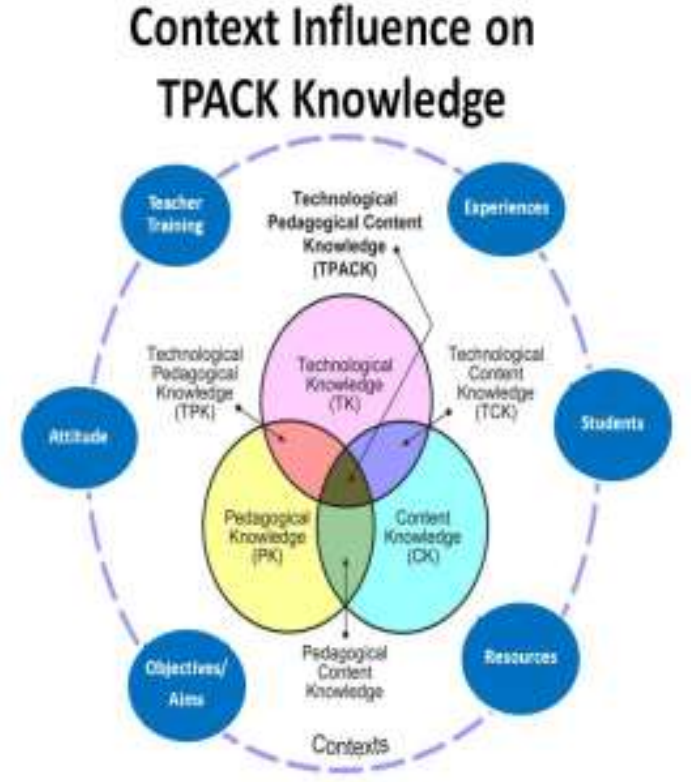

"There are seven components of TPACK model as given by Shulman:

1. Technological Knowledge (TK): Technology knowledge refers to how to use computer software and hardware presentation tools \& other technologies used in educational contexts.

2. Content Knowledge (CK): Content knowledge refers to the Teacher's knowledge about the subject matter to be learned or taught.

3. Pedagogical Knowledge (PK): Pedagogical knowledge refers to the set of skills teachers must develop and teacher's deeper knowledge about the processes and methods/techniques of teaching \& learning.

4. Pedagogical Content Knowledge (PCK): Pedagogical content knowledge refers to the knowledge of the subject/topic, psychology of the learner, psychology of learning etc. are the important factors that determine the appropriate selection of the methods/techniques for teaching. For example: art, drama, puppetry, role play, nature rambling, field trips, laboratory method, project method etc.

5. Technological Content Knowledge (TCK): Technological content knowledge refers to an understanding of the manner in which technology and content influences one another Teacher should be aware of the innovative technologies available in the global market for the effective transaction of the subject matter. For example: Virtual Labs, Virtual field trips, e-library, educational softwares etc.

6. Technological Pedagogical Knowledge (TPK): Technological pedagogical knowledge refers to the reciprocal relationship between technology and pedagogy. An understanding of how teaching and learning can change when technologies are used in particular ways. This includes knowing technological tools for appropriate pedagogical designs and strategies. For example, collaborative writing can take place with Google Docs or Google Hangouts instead of face-to-face meetings.

7. Technological Pedagogical Content Knowledge (TPACK): TPACK as a synthesised resource of Technological knowledge (TK), Content knowledge (CK), Pedagogical knowledge (PK), Pedagogical content knowledge (PCK), Technological content knowledge (TCK),

Technological pedagogical knowledge (TPK) with a focus upon how technology can be uniquely crafted to meet pedagogical needs to teach certain content in specific contexts so as to ensure fruitful learning."

However, seeing the aforesaid state of affairs, the primary purpose of the present study is to assess the TPACK skills among teacher-educators working in different teacher-training colleges in the state of PUNJAB (India).

\section{REVIEW OF RELATED LITERATURE}

The conquest of any educational practices' rests on the understanding and familiarity of teacher educators towards the efficient use of TPACK competencies in whole education process. Understanding the knowledge and levels of teacher educators towards TPACK matters a lot and is very essential. Also vital is to know the levels of technological tools or devices used in teaching learning process to make efficient prospective teachers (Huang and Liaw, 2005). Teacher-educators are the effective and dominating factors among the ones contributing to educational improvements. They are required to have TPACK competencies to make teaching-learning process effective. (Kalogiannakis, 2010).

Technologies have played a dominating role in the whole education process. Researchers have shown techno-pedagogical competencies support higher-level learning and thinking skills among students. It's proved to have positive effects in language learning and it becomes as an integral part of education and contributed as teaching tools in the language classroom. There is a great deal of interest to learn more about the potential use of TPACK in education practices.

Meanwhile, a number of studies show that the successful implementation of techno-pedagogical competences in teaching learning process make educational practices more productive and efficient and provide a better learning engagement experiences. (Leask \& Pachler, 2014). When used appropriately, techno-pedagogical competences have high potential to enhance teaching and learning, and will provide good opportunities for pre service teachers to improve their techno-pedagogical competences. (Haddad \& Draxler, 2002; Oliver, 2005). As new technological innovations are rapidly introduced and changed, identifying an individual innovativeness that has a persistent effect on the acceptance decisions across multiple technologies is of substantial value for the successful implementation of techno-pedagogical competences.

The TPACK model was established by extending Shulman (1986) pedagogical content knowledge (PCK) and accumulating technology to it (Mishra \& Koehler, 2006). "TPACK embraces the presentation of concepts using technology: knowledge about using technology productively to teach content, knowledge about what complicates or facilitates learning concepts, knowledge about the ways technology can help students understand difficult subjects, knowledge about the ways knowledge and technologies are used to add new information to existing information, to 
develop new epistemology or to foster existing information about students' present knowledge and epistemology" (Mishra \& Koehler, 2006).

Beaudin and Hadden (2004) revealed in their research that "techno-pedagogical skill raises the students for further improvement, attainment of learning outcomes and maintain the context of designing classroom-based resources through the use of technology by the teachers. Therefore, techno-pedagogy method was an essential component of teacher education." The National Curriculum Framework (2009) stated that "ICT can be imaginatively drawn upon for professional development and academic support of the pre-service and in-service teachers." Lee and Tsai (2010) stated that "meaningful use of ICT in the classroom demands the teachers to integrate technological affordances with pedagogical approaches for the specific subject matter to be taught".

\section{OBJECTIVES OF THE STUDY}

- To study the technological pedagogical and content knowledge (TPACK) competencies among teacher-educators of Punjab region.

- To study the technological pedagogical and content knowledge (TPACK) competencies among teacher-educators with respect to gender (male/female).

- To study the technological pedagogical and content knowledge (TPACK) competencies among teacher-educators with respect to locality of college (rural/urban).

- To study the technological pedagogical and content knowledge (TPACK) competencies among teacher-educators with respect to stream (arts/science).

- To study the technological pedagogical and content knowledge (TPACK) competencies among teacher-educators with respect to type of colleges (government \& govt. aided/private).

\section{SAMPLE}

Random sampling technique was employed for gathering data. The research participants were the teacher educators working in different teacher training colleges in the state of Punjab (India). The sample of the study was confined to 200 teacher educators from government/ government aided, and private B.Ed colleges working under Punjabi, Panjab and Guru Nanak Dev University in the Punjab State (India).

\section{PROCEDURE}

In this present study, a survey method was applied for collecting data. A self-constructed questionnaire consisted of five-point Likert scale was used by the researchers to collect data from 200 teacher educators working in different teacher training colleges in the State of Punjab (India). The format of five-point Likert scale constitute (strongly agree $=5$, agree $=4$, neutral $=3$, disagree $=2$, strongly disagree $=1$ ).

\section{TOOL USED FOR THE STUDY}

\section{Description}

A five- point Likert scale constructed \& validated by researchers was used to study the technological pedagogical and content knowledge (TPACK) competencies among teacher educators in teacher training colleges at Punjab region. The tool consists of 30 items with five responses, such as strongly agree, agree, neutral, disagree and strongly disagree.

\section{Scoring Procedure}

All the items of the tool are positive statements. Hence, the scoring procedure as follows, 5- strongly agree, 4-agree, 3-neutral, 2- disagree and 1- strongly disagree.

\section{Reliability and Validity of the Scale}

The Cronbach's alpha coefficient of TPACK competency scale which is .82 ensures high reliability. High reliability value ensures high validity which was examined using Exploratory Factor Analysis (EFA).

\section{Statistical tools used}

The investigators used the descriptive and differential analyses in this investigation.

\subsection{Analysis procedure}

After collecting the data from 200 teacher educators working under teacher training colleges in the State of Punjab, the data was evaluated by using Statistical Package for Social Science (SPSS) program. SPSS program was used to interpret data and produce results of the present study.

\subsection{Analysis and Interpretation of results}

Analysis and interpretation of results are discussed under the following headings.

Hypothesis (1): A technological pedagogical and content knowledge (TPACK) competency among teacher-educators in the region of Punjab is high.

Descriptive Statistics

\begin{tabular}{|l|r|r|r|r|r|r|}
\hline & $\mathrm{N}$ & $\begin{array}{r}\text { Mini } \\
\text { mum }\end{array}$ & $\begin{array}{c}\text { Maximu } \\
\mathrm{m}\end{array}$ & Mean & $\begin{array}{c}\text { Percent } \\
(\%)\end{array}$ & $\begin{array}{c}\text { Std. } \\
\text { Deviation }\end{array}$ \\
\hline $\begin{array}{l}\text { Means_Indi } \\
\text { vidual } \\
\text { Valid N } \\
\text { (listwise) }\end{array}$ & 200 & 4.00 & 5.00 & 4.5065 & 90.13 & .26862 \\
\hline
\end{tabular}

Table 1.1

From the above table (1.1) shows that the mean score of all 200 teacher-educators is 4.50 which shows that the all teacher-educators in the Punjab region have high TPACK competencies i.e. $90.13 \%$. Hence the stated hypothesis is accepted which shows that technological pedagogical and content knowledge (TPACK) competency among teacher-educators in the region of Punjab is high. 
International Conference on Recents Advancements in Engineering and Technology (ICRAET-18) |15th and 16th March 2019|Siddhartha Institute of Technology \& Sciences, Telangana, India.

Table-1.2: Showing the mean, standard deviation, Sig. value of Levene's Test for equality of variances, Sig. value of t-test for equality of means with respect to different Sub-samples.

\begin{tabular}{|c|c|c|c|c|c|c|c|}
\hline Sample & $\begin{array}{c}\text { Sub-Sam } \\
\text { ple }\end{array}$ & $\mathbf{N}$ & Mean & SD & $\begin{array}{l}\text { Sig. value of } \\
\text { Levene's Test } \\
\text { for Equality of } \\
\text { Variances }\end{array}$ & $\begin{array}{l}\text { significant } \\
\text { value of } \\
\text { t-test for } \\
\text { equality of } \\
\text { means }\end{array}$ & $\begin{array}{c}\text { Level of } \\
\text { Significance }\end{array}$ \\
\hline \multirow{3}{*}{ Gender } & Male & 110 & 4.4485 & .28402 & \multirow[t]{3}{*}{.008} & \multirow[t]{3}{*}{.001} & \multirow[t]{3}{*}{ Significant } \\
\hline & & & & & & & \\
\hline & Female & 90 & 4.5774 & .23088 & & & \\
\hline \multirow{3}{*}{ Locality } & Rural & 76 & 4.4531 & .25666 & \multirow[t]{3}{*}{.310} & \multirow[t]{3}{*}{.027} & \multirow[t]{3}{*}{ Significant } \\
\hline & Urban & & & & & & \\
\hline & & 124 & 4.5392 & .27154 & & & \\
\hline \multirow[b]{2}{*}{ Stream } & Arts & 98 & 4.3643 & .24398 & \multirow[t]{2}{*}{.460} & \multirow[t]{2}{*}{.000} & \multirow[t]{2}{*}{ Significant } \\
\hline & Science & 101 & 4.6406 & .21523 & & & \\
\hline \multirow{3}{*}{$\begin{array}{l}\text { Type of } \\
\text { Colleges }\end{array}$} & Gt./Gt. & 69 & 4.3121 & .19037 & \multirow[t]{3}{*}{.001} & \multirow[t]{3}{*}{.000} & \multirow[t]{3}{*}{ Significant } \\
\hline & Aided & & & & & & \\
\hline & Private & 131 & 4.6089 & .24672 & & & \\
\hline
\end{tabular}

Table 1.2

Hypothesis (2): There is no significant difference in the technological pedagogical and content knowledge (TPACK) competencies among teacher-educators with respect to gender (male/female).

The above table no. 1.2 shows that the mean of male teacher-educators is 4.44 whereas mean of female teacher-educators is 4.57 , which shows that the TPACK competency of female teacher-educators is moderately high than male teacher-educators. As well as table 1.2 shows the significant level of Lavene's Test for Equality of Variance is .008 which is less than .05 , shows that the variance occurs in the means of male and female. As well as significant value of t-test for equality of means .001 which shows that the stated hypothesis is rejected. Therefore we can conclude that the female teacher-educators have significantly difference in TPACK competencies than the male teacher-educators.

Hypothesis (3): There is no significant difference in the technological pedagogical and content knowledge (TPACK) competencies among teacher-educators with respect to locale (rural/urban).

The above table 1.2 depicts that the mean of rural teacher-educators is 4.45 whereas the mean of urban teacher-educators is 4.53 , which shows that the TPACK competencies of urban teacher-educators is high in comparison to rural teacher-educators. As well as Table 1.2 shows the significant level of Lavene's Test for Equality of Variance is .310 which is greater than .05 , shows that variance occurs in the means of rural and urban. As well as significant value of t-test for equality of means is .027 which shows that stated hypothesis is rejected.

Therefore we can conclude that the urban teacher-educators have significantly difference in TPACK

competencies than the rural teacher-educators.

Hypothesis (4): There is no significant difference in the technological pedagogical and content knowledge (TPACK) competencies among teacher-educators with respect to stream (arts/science).

The above table 1.2 shows that the mean of teacher-educators from arts background is 4.36 whereas the mean of teacher-educators from science background is 4.64, which shows that the TPACK competencies of Science teacher-educators is high in comparison to arts teacher-educators. As well as Table 1.2 shows the significant level of Lavene's Test for Equality of Variance is .460, which shows that variance occurs in the means of arts and science. As well as the significant value of t-test for equality of means is .000 which indicates that the stated hypothesis is rejected. Therefore we can conclude that the teacher-educators from science background have significantly difference in TPACK Competencies than the teacher-educators from arts background.

Hypothesis (5): There is no significant difference in the technological pedagogical and content knowledge (TPACK) competencies among teacher-educators with respect to type of colleges (government \& government aided/private).

The above table 1.2 shows that the mean of Govt./Govt. Aided teacher-educators in the state of Punjab is 4.31 whereas the mean score of private college's teacher-educators is 4.60 , which shows that the TPACK competencies of private colleges' teacher-educators is high in comparison to the teacher educators from Govt./Govt. Aided colleges. As well 
as Table 1.2 shows the significant level of Lavene's Test for Equality of Variance is .001 which is less than .05, shows that variance occurs in the means of Govt./Govt. Aided teacher-educators. As well as significant value of t-test for equality of means is .000 , which states that the stated hypothesis is rejected.Therefore we can conclude that the private teacher-educators have significantly difference in (TPACK) competencies than the government /government aided teacher educators.

\section{MAJOR FINDINGS OF THE STUDY}

1. Techno-pedagogical and content knowledge (TPACK) competencies among teacher-educators in Punjab state is high.

2. Techno-pedagogical and content knowledge (TPACK) competencies among teacher-educators with respect to female is moderately high than male.

3. Techno-pedagogical and content knowledge (TPACK) competencies among teacher-educators from urban back-ground is high than teacher-educators from rural background.

4. Techno-pedagogical and content knowledge (TPACK) competencies among teacher-educators from science back-ground is high than teacher-educators from arts background.

5. Techno-pedagogical and content knowledge (TPACK) competencies among teacher-educators from private colleges is high than teacher-educators from government/ government-aided colleges.

\section{IMPLICATIONS OF THE STUDY}

1. Integration of technology, content and pedagogy knowledge helps the teacher to teach effectively in the present scenario. TPACK helps the teacher-educators to update their knowledge and skills which leads to enhance their professional development.

2. Technology enhanced class room climate promotes confidence among learners, encourage to learn, easy to access at their convenience and long term retention will be there.

3. TPACK classroom climate provides the teacher and students to communicate (Share knowledge, ideas, views, opinions) with others locally and globally.

\section{LIMITATIONS AND FUTURE RESEARCH}

\subsection{Limitations}

The results of this study show the TPACK competencies among teacher-educators with respect to gender, locality of college, stream and type of colleges. The findings of the study does not report on the long-term impact of TPACK competencies on teacher-educators as technology alters very rapid and how teacher-educators will be able to update their skills, classroom content and mode of delivery frequently.

\subsection{Future studies}

Several aspects can be considered in future studies. The present study stresses that techno-pedagogical and content knowledge (TPACK) competencies among teacher educators in State of Punjab (India). It can be further conducted on teacher-educators of other state as well as national level. The sample of the current study is the teacher-educators working in different teaching training colleges in Punjab region. The sample can be taken as pre-service teachers. This study can be used to further examine the influence of TPACK competencies on the academic achievement of students.

In this study, TPACK competencies of teacher-educators were assessed through filling questionnaire by the teacher-educators but the actual implementation in class were not studied. In future research, the actual implementation of content material designed using TPACK competencies can be used to further understand teachers' design capacities of TPACK with respect to the educational outcomes produced.

\section{CONCLUSION}

This research was carried out with a aim of assessing technological pedagogical and content knowledge (TPACK) competencies of teacher-educators in the region of Punjab (India). In line with this aim, teacher-educators' levels of TPACK competencies were studied in terms of gender, locality, stream and type of colleges. The findings of the study reveal that the teacher-educators in the sample group of the study have high TPACK competencies, in general.

According to the findings of the study, based on gender, locality, stream and type of colleges, there are statistically significant differences among teacher-educators' TPACK competencies. The study throws light into the fact that female teacher-educators have moderately high TPACK competencies than male teacher-educators. Teacher-educators from urban background have high TPACK competencies than teacher-educators from rural backgrounds. Teacher-educators from science background have high TPACK competencies than teacher-educators from arts background. As well as teacher-educators of private colleges have high TPACK competencies than teacher-educators of government/government aided colleges in the region of Punjab (India). Hence the current study stresses the importance of male teacher-educators in Punjab region to improve their technological pedagogical and content knowledge (TPACK) competencies. Further teacher-educators from rural background, arts stream and government/government-aided teacher-educators to improve their technological pedagogical and content knowledge (TPACK) competencies.

Thus, as a fraternity of teachers we should know how to weave technology, content, and pedagogy effectively in their class room interaction. Lack of knowledge in the part of teacher-educators in terms of gender, locality, stream and type of colleges regarding technological pedagogical and content knowledge (TPACK) competencies is found to be a slight constraint in blending these three major aspects. 


\section{REFERENCES}

1. Albion, P., \& Ertmer, P. A. (2002). Beyond the foundations: The role of vision and belief in teachers' preparation for integration of technology. Tech Trends, 46 (5), 34-38.

2. ASTC (2010). Assessment \& Teaching of 21 st Century Skills. Retrieved March 30, 2014 from: http://atc21s.org/wp-content/uploads/2011/04/January20 10StatusReport.pdf

3. Bowes, J. (2003). The emerging repertoire demanded of teachers of the future: Surviving the transition, retrieved, September 1, 2004, from http://crpit.com/confpapers/CRPITV23Bowes.pdf.

4. Bradley, G., \& Russell, G. (1997). Computer experience, school support and computer anxieties. Educational Psychology, 17 (3), 267-284.

5. Bransford, J. D., Brown, A. L., \& Cocking, R. R. (2000). How people learn: Brain, mind, experience, and school (Expanded ed.). Washington, D.C.: The National Academies.

6. Bransford, J. D., Darling-Hammond, L., \& LaPage, P. (2005). Introduction. In L. Darling-Hammond \& J. Bransford (Eds.), Preparing teachers for a changing world: What teachers should learn and be able to do (pp. 358-389). San Francisco: Jossey-Bass.

7. Brzycki, D., \& Dudt, K. (2005). Overcoming barriers to technology use in teacher preparation programs.Journal of Technology and Teacher Education, 13(4), 619-641.

8. Bullock, D. (2004). Moving from theory to practice: An examination of the factors that preservice teachers encounter as the attempt to gain experience teaching with technology during field placement experiences. Journal of Technology and Teacher Education, 12(2), 211-237.

9. Erkan, S. (2004). An analysis on teachers' attitudes towards computer. Manas University, Journal of Social Science, 17(12), 123-132.

10. Ertmer, P.A. (1999). Addressing first and second order barriers to change: Strategies for technology integration. Education Technology Research and Development, 47(4), 47-61.

11. Fabry, D. \& Higgs, J. (1997), 'Barriers to the effective use of technology in education', Journal of Educational Computing, 17 (4), pp. 385-395.

12. Gomez, L. M., Sherin, M. G., Griesdorn, J., \& Finn, L. (2008). Creating social relationships: The role of technology in preservice teacher preparation. Journal of Teacher Education, 59(2), 117-131.

13. Goktas, Y., Yildirim, S., \& Yildirim, Z. (2009). Main barriers and possible enablers of ICTs integration into pre-service teacher education Programs. Educational Technology \& Society, 12(1), 193-204.

14. Gray, L., Thomas, N., \& Lewis, L. (2010). Teachers' use of educational technology in U.S. public schools: 2009. National Center for Education Statistics. Institute of Education Science, U.S. Department of Ed-ucation. Washington DC.

15. Gronseth, S., Brush, T., Ottenbreit-Leftwich, A., Stryker, J., Abaci, S., Easterling, W., \& van Leusen, P. (2010). Equipping the next generation ofteachers: Technology preparation and practice. Journal of Avidov-Ungar \& Iluz 213 Digital Learning in Teacher Education, 27(1), 20-26. Retrieved March 31, 2014 from http://mypage.iu.edu/ sgronset/2010-JDLTE-27-1-030.p df

16. Guha, S. (2000), 'Are we all technically prepared? Teachers' perspective on the causes of comfort or discomfort in using computers at elementary grade teaching', paper presented at the Annual Meeting of the National Association for the Education of Young
Children,Atlanta, GA, November 8-11.

17. Haddad, W \& Draxler, A. (2002). Technologies for Education. Paris. UNESCO and the Academy for Educational Development.

18. http://citeseerx.ist.psu.edu/viewdoc/download?doi=10.1.1. $110.9338 \&$ rep=rep $1 \&$ type $=$ pdf

19. http://www.macrothink.org/journal/index.php/jsr/article/vi ew/1882

20. Huang, H. M., \& Liaw, S. S. (2005). Exploring user's attitudes and intentions toward the web as a survey tool Computers in Human Behavior, 21(5), 729-743.

21. Kalogiannakis, M. (2010). Training with ICT for ICT from the Trainer's Perspective. A Local ICT TeacherTraining Experience. Education and Information Technologies 15 (1): 3-17.

22. Karpati, A., Torok, A., \& Szirmai, A.L. (2008). E-teaching readiness of teachers: the effects of personality traits and ICT skills on changes in teaching style of experienced educators. In Proceedings of the VIIth Research Workshop of EDEN, Paris, 6-8 October 2008.

23. Kipsoi, E., Changach, J. \& Sang, H. (2012).Challenges facing adoption of implementation of communication technology in educational management in schools in Kenya. Journal of Sociological research. 3(1), 18-28.

24. Laaria, M. (2013). Leadership challenges in the implementation of ICT in public secondary schools, Kenya, Journal of education and learning. 2(1). 32-43.

25. Larner, D. \& Timberlake, L. (1995),'Teachers with limited computer knowledge: variables affecting use and hints to increase use', The Curry School of Education, University of Virginia. Learning. Computers and Education, 47(1), 17-28.

26. Leask, M. \& Pachler, N. (2014). Learning to teach using ICT in secondary schools. A Companion to school experience, 38 (2), 27-34.

27. Leggett, W. P., \& Persichitte, K. A., (1998). Blood, sweat, and TEARS: 50 years of technology Implementation obstacles. TechTrends, 43(3), 33-36.

28. McCarrick, K., \& Li, X., (2007). Buried treasure: The impact of computer use on young children's social, cognitive, language development and motivation. Association for the Advancement of Computing In Education Journal, 15, 73-95.

29. McKinsey Report. (2007). How the world's best-performing school systems come out on top Retrieved April 2, 2014, from: http://www.teacherqualitytoolbox.eu/news/4

30. Ministry of Education, Administration of Training and Professional Development of Teaching Personnel, Department of Training for Teaching Personnel. (2011). Adapting Teacher Training Colleges to 21st Century Education. Retrieved April 2nd, 2014, from:

31. http://cms.education.gov.il/educationcms/units/madatech/i ctineducation

32. Oliver, R., (2005). The role of ICT in higher education for the 21st century: ICT as a change agent for education. http://citeseerx.ist.psu.edu/viewdoc/summary?doi=10.1.1 .83.9509.

33. Pelgrum,W., (2001), 'Obstacles to the integration of ICT in education: results from a worldwide educational assessment', Computers and Education, 37, pp. 163-178.

34. Prestridge, S., (2012). The beliefs behind the teacher that influences their ICT practices. Computers \& Edu-cation, 58(1), 449-458. 
35. Rohaan, E. J., Taconis, R., \& Jochems, W. M. G. (2010). Reviewing the relations between teachers" knowledge and pupils $^{\text {ee }}$ attitude in the field of primary technology education. International Journal of Technology and Design Education, 20, 15-26.

36. Snoeyink, R. \& Ertmer, P., (2001), 'Thrust into technology: how veteran teachers respond', Journal of Educational Technology Systems, 30 (1), pp. 85-111.

37. Teo, T., (2008). Pre-service Teachers' attitudes towards computer use: A Singapore survey. Australasian Journal of Educational Technology, 24(4), 413-424.

38. Teo, T., Lee, C. B., \& Chai, C. S., (2008). Understanding pre-service teachers' computer attitudes: applying and extending the Technology Acceptance Model (TAM). Journal of Computer Assisted Learning, 24(2), 128-143.

39. Tsou, W., Wang, W. \& Tzeng, Y., (2006). Applying a Multimedia Storytelling Website in Foreign Language Vol. 1, pp. 80-99.

40. Watson, D. M., (1998). Blame the technocentric artifact! What research tells us about problems inhibiting teacher use of IT. In G. Marshall, \& M. Ruohonen (Eds.), Capacity building for IT in education in developing countries, 185-192. London: Chapman \& Hall.

41. Yuksel G, Nuray G \& Ozlem B., (2013) 'Enablers and barriers to the use of ICT in primary schools in Turkey: A comparative study of 2005-2011', Computers \& Education, 68, pp. 211-222.

42. Yusuf, M.O., (2005). Information and communication education: Analyzing the Nigerian national policy for information technology. International Education Journal Vol. 6 No. (3), Pp; 316-321. 